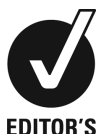

${ }^{1}$ Department of Respiratory Medicine, Kyorin University School of Medicine, Mitaka, Japan

${ }^{2}$ Department of Pathology, Kyorin University School of Medicine, Mitaka, Japan

\section{Correspondence to}

Dr Takeshi Saraya, sara@yd5.so-net.ne.jp

Accepted 2 May 2015
CrossMark

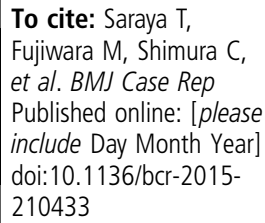

\title{
Not paraneoplastic pemphigus but pemphigus vulgaris in a patient with thymoma
}

\author{
Takeshi Saraya, ${ }^{1}$ Masachika Fujiwara, ${ }^{2}$ Chie Shimura, ${ }^{1}$ Hajime Goto ${ }^{1}$
}

\section{DESCRIPTION}

A 54-year-old man with thymoma (figure 1A, arrow) diagnosed 8 months previously was referred to our hospital because of a 5-month history of painful oral ulcer and odynophagia. Physical examination showed erosion of the lips, pharynx, tongue and buccal mucosa (figure 1B, arrow), together with scrotal skin change (appearing similar to lichen planus; figure $1 \mathrm{C}$, arrow heads) and scrotal erosion (figure 1C, arrow). On H\&E staining, scrotum-biopsied specimens showed suprabasilar blisters with acantholysis (figure 1D, asterisk). On direct immunofluorescence, intercellular IgG and $\mathrm{C} 3$ deposits were noted, but not at the basement membrane. Indirect immunofluorescence studies of dilutions of the patient's serum applied to a human skin substrate revealed circulating antibodies that bound to the intercellular regions (not to basement-membrane zones) of the epithelium at a titre of $1-160$, whereas that applied to a rodent bladder substrate (negative control slides) did not. All serum antibodies to desmoplakin I and II, envoplakin and periplakin and desmoglein 1, were negative, but only serum desmoglein 3 antibody was positive on CLEIA (chemiluminescence enzyme immunoassay) (1:840) or ELISA (269.85).
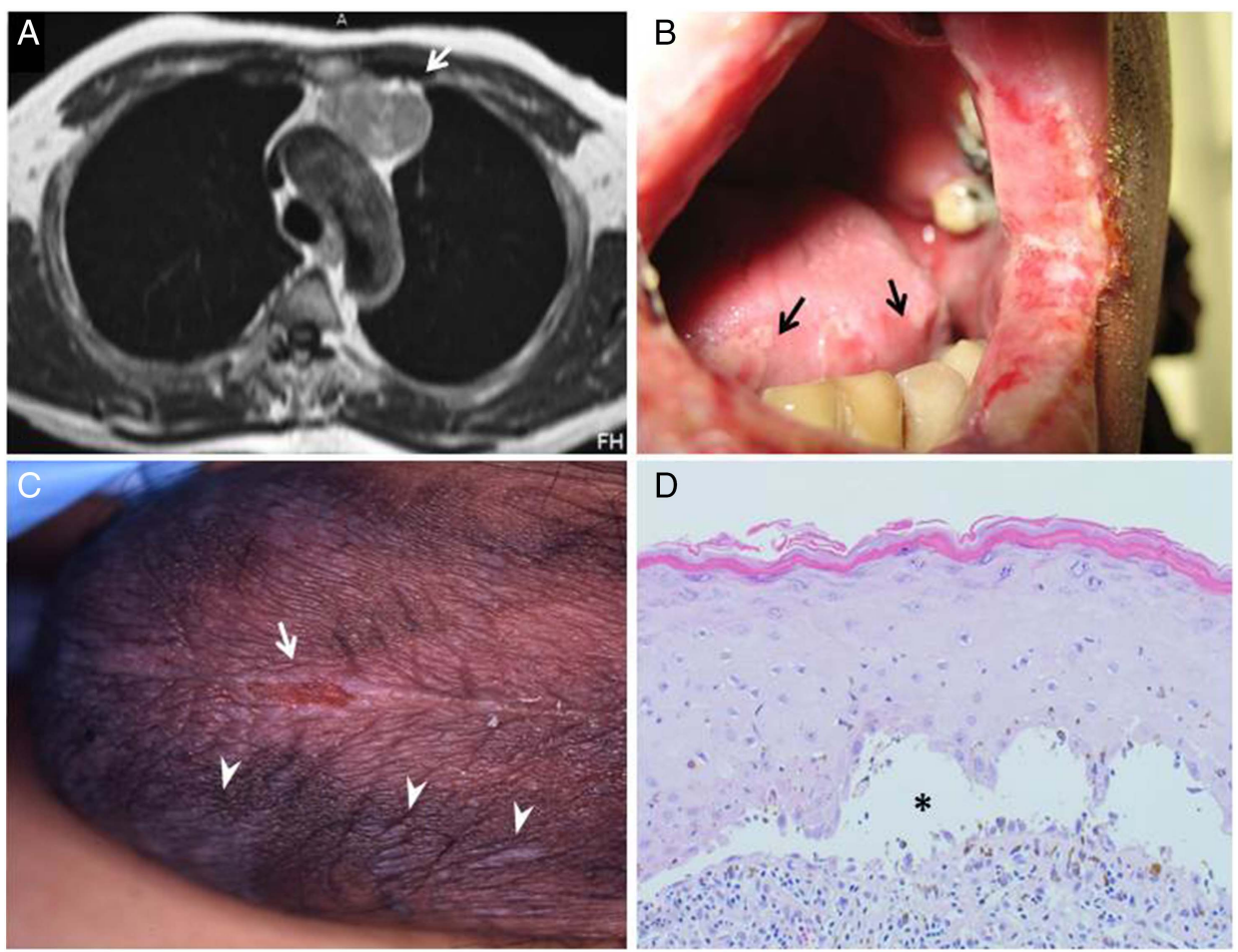

Figure 1 Enhanced thoracic MRI showed the presence of a homogenously enhanced $3 \mathrm{~cm}$ mass. Mucous membrane erosion of the lips, pharynx, tongue and buccal mucosa ( $B$, arrow) were noted together with scrotal skin change $(C$, arrow heads) and scrotal erosion (C, arrow). On H\&E staining, scrotum-biopsied specimens showed suprabasilar blisters with acantholysis ( $D$, asterisk). 
producing a suprabasal cleft, as in the present case. Whereas in PNP, antibodies to desmosomal and hemidesmosomal proteins are associated with both suprabasal and subepithelial clefting.

PNP and PV have similar clinical presentations but have different pathophysiologies ${ }^{12}$ in that (1) PV shows more favourable prognosis than PNP and (2) PNP often lead to pulmonary involvement. PNP is known to associate with diverse conditions such as Non-Hodgkin's lymphomas, chronic lymphocytic leucaemia, Castleman's disease, thymoma and Waldenstrom's macroglobulinaemia; however, PV should be considered even if those possible underlying diseases for which PNP is recognised.

Acknowledgements The authors thank Fumito Ishii and Takashi Hashimoto (Kurume University School of Medicine, Department of Dermatology) for immunological analysis with serum autoantibodies and also thank Dr Jun Hayakawa
(Kyorin University School of Medicine, Department of Dermatology) for useful advice on interpreting the clinical findings.

Contributors TS, CS and HG managed the patient in an inpatient setting. MF analysed the pathological findings.

Competing interests None declared.

Patient consent Obtained.

Provenance and peer review Not commissioned; externally peer reviewed.

\section{REFERENCES}

1 Wade MS, Black MM. Paraneoplastic pemphigus: a brief update. Australas J Dermatol 2005;46:1-8; quiz 9-10.

2 Ahmed AR, Avram MM, Duncan LM. Case records of the Massachusetts General Hospital. Weekly clinicopathological exercises. Case 23-2003. A 79-year-old woman with gastric lymphoma and erosive mucosal and cutaneous lesions. N Engl I Med 2003;349:382-91.

Copyright 2015 BMJ Publishing Group. All rights reserved. For permission to reuse any of this content visit

http://group.bmj.com/group/rights-licensing/permissions.

BMJ Case Report Fellows may re-use this article for personal use and teaching without any further permission.

Become a Fellow of BMJ Case Reports today and you can:

- Submit as many cases as you like

- Enjoy fast sympathetic peer review and rapid publication of accepted articles

- Access all the published articles

- Re-use any of the published material for personal use and teaching without further permission

For information on Institutional Fellowships contact consortiasales@bmjgroup.com

Visit casereports.bmj.com for more articles like this and to become a Fellow 